\title{
Histone-Lysine N-Methyltransferase 2E
}

National Cancer Institute

\section{Source}

National Cancer Institute. Histone-Lysine N-Methyltransferase 2E. NCI Thesaurus. Code C93096.

Histone-lysine N-methyltransferase MLL5 (1858 aa, $204 \mathrm{kDa}$ ) is encoded by the human MLL5 gene. This protein is involved in the methylation of histone proteins, the modulation of cell cycle progression and the regulation of gene transcription. 